\title{
Positifikasi Hukum Keluarga di Dunia Muslim melalui Pembaharuan Hukum Keluarga
}

\author{
Lilis Hidayati Yuli Astutik ${ }^{1}$, Muhammad Ngizzul Muttaqin ${ }^{2}$ \\ 1,2 Mahasiswa Pascasarjana Institut Agama Islam Negeri Tulungagung \\ e-mail: lilisbys@gmail.com, muttaqinizzul19@gmail.com
}

\begin{abstract}
ABSTRAK. Penggunaan fikih klasik dalam bidang hukum keluarga kontemporer nampaknya tidak lagi bisa merespon problematika dan perkembangan masyarakat hari ini. Pembaharuan hukum keluarga Islam yang kemudian dijadikan sebuah aturan Negara dirasa menjadi sebuah solusi yang sangat relevan dalam rangka merespon problematika hukum keluarga kontemporer. Sebagai kajian berbasis literatur dan kajian pustaka, tulisan ini berusaha mengungkap model pembaharuan hukum keluarga di berbagai Negara muslim sebagai langkah awal untuk membuat hukum positif dalam sebuah Negara. Tulisan ini perlu diseminasikan agar memberikan sebuah pemahaman terkait pengembangan hukum keluarga Islam melalui pembaharuan dan proses positifikasi hukum keluarga dalam sebuah Negara. Metode pengumpulan data dalam kajian ini dengan menelaah refrensi yang relevan dalam penyajian data. Temuan dalam kajian ini bahwa pembaharuan hukum keluarga dilakukan untuk menjawab permasalahan masyarakat yang semakin kompleks. Pertimbangan pembaruan hukum keluarga Islam di dunia muslim adalah mencapai sebuah kemaslahatan umat. Implikasi temuan kajian ini bahwa positifikasi hukum keluarga di dunia Islam sangat penting, sebagai respon terhadap perkembangan zaman. Selain itu, wujud dari pembaharuan akan melahirkan sebuah fikih atau paham yang sejalan dengan perubahan kondisi masyarakat.
\end{abstract}

\begin{abstract}
The use of classical fiqh in the field of contemporary family law seems to be no longer able to respond to problems and development of society today. Renewal of Islamic Family law which was then made a rule of the country is considered a very relevant solution in order to respond to the problem of contemporary family law. As a research and literaturebased study, this article seeks to uncover the model of family law renewal in various Muslim countries as a first step to create positive laws in a country. This paper needs to be dissemination in order to provide an understanding of the development of Islamic family law through the renewal and positivity process of family law in a country. Method of collecting data in this study by studying the relevant references in the presentation of data. The findings in this review that family law reform is done to address the increasingly complex problems of society. Consideration of renewal of Islamic family law in the Muslim world is reaching a benefit of the people. The implication of the findings is that the positification of family law in the Islamic world is crucial, in response to the development of the Times. In addition, the form of renewal will produce a fiqh or understanding that is in line with changes in community conditions.
\end{abstract}

Kata kunci: Positifikasi, Pembaharuan, Hukum Keluarga, Dunia Muslim.

\section{PENDAHULUAN}

Beberapa permasalahan yang menyangkut unsur hukum keluarga selalu bermunculan dan perkembangan seiring dengan perbedaan tempat dan waktu. Hal ini yang selanjutnya menuntut adanya sebuah perangkat hukum yang ada harus bisa menyelesaikan dan 
mengakomodir beberapa permasalahan kontemporer yang muncul. Salah satu permasalahan yang akan selalu muncul adalah isu gender dan penyetaraan antara laki-laki dan perempuan. Hal itu, disebabkan selama dalam aktivitas rumah tangga. Perempuan selalu diidentikkan dengan sebuah pekerjaan di bawah laki-laki, yang selanjutnya disebut dengan penindasan terhadap peremuan. ${ }^{1}$ Permasalahan ini yang kemudian menuntut untuk segera diselesaikan dengan terobosan-terobosan hukum yang lebih ramah terhadap kaum perempuan.

Hukum keluarga mempunyai sebuah posisi penting dalam diskursus kajian hukum Islam. Hal ini disebabkan oleh sebuah pemahaman yang menyatakan bahwa hukum keluarga merupakan gerbang utama dalam memasuki ketentuan-ketentuan hukum Islam selanjutnya. ${ }^{2}$ Pada pertengahan abad ke-20, hukum keluarga mengalami reformasi dan beberapa pembaharuan. Negara yang pertama kali melakukan ini adalah Negara Turki yang kemudian diikuti oleh Negara Mesir dan terus diikuti oleh berbagai Negara dalam pembaharuan hukum keluarga.

Pengalihan dari fikih konvensional menuju Undang-Undang hukum keluarga kontemporer disebabkan oleh aturan-aturan yang ada. Dalam fikih konvensional dianggap tidak bisa memberikan solusi terhadap berbagai persoalan kontemporer yang ada. Maka, tujuan utama adanya pembaharuan hukum keluarga ini adalah untuk melindungi dan meningkatkan derajat kaum perempuan. Selain itu, untuk menyelesaikan permasalahanpermasalahan yang tidak bisa terjawab oleh fikih konvensional.

Pembaharuan hukum keluarga ini kemudian bisa ditelusuri dalam positifikasi hukum keluarga di Negara-negara Islam. Positifikasi hukum keluarga ini memiliki beberapa kecenderungan, hal itu sebagai gerakan dan desakan dari beberapa kelompok untuk mengadakan amandemen hukum keluarga klasik menuju hukum keluarga kontemporer. Gerakan ini banyak dipelopori oleh kelompok liberal, modernis, dan feminis juga diccetuuskan oleh kelompok-kelompok intelektual konvertif seperti Grad Syaikh al-Azhar dan Muhammad Sayyid Tantawi. ${ }^{3}$

Beberapa pembaharuan hukum keluarga ini dapat ditemukan dalam berbagai Negara yang memiliki mayoritas penduduk yang beragama Islam. ${ }^{4}$ Dalam konteks pembaharuan hukum keluarga yang merupakan modernisasi hukum keluarga setidaknya ada tiga pandangan dari berbagai Negara. ${ }^{5}$ Pertama, Negara yang memiliki faham sekuler, dimana hukum keluarganya bersumber dari hukum barat, seperti Uni Soviet, Turki, Albania. Kedua, Negara yang memberlakukan hukum keluarga Islam klasik yang bersumber dari kitab-kitab fikih klasik, seperti Saudi Arabia, Kuwait, Afganistan, dan Yaman. Ketiga, Negara yang memiliki paham hukum keluarga klasik yang diperbaharui dan dijadikan sebuah aturan Undang-undang, seperti Indonesia, Malaysia, Jordania, Brunei Darussalam, dan Maroko.

Ilustrasi dan penjelasan di atas, kiranya telah menggelitik penulis untuk melakukan sebuah kajian dalam rangka mengetahui proses pembaharuan hukum keluarga dari konsep

1 Abdul Ghofur dan Sulistiyono, "Eklektisisme dalam Taqnin Hukum Keluarga di Dunia Islam" (ISLAMICA: Jurnal Studi Keislaman, Volume 8, Nomor 2, Maret 2014), h. 261-262.

2 Eko Setiawan, "Dinamika Pembaharuan Hukum Keluarga Islam di Indonesia" (de jure: Jurnal Syariah dan Hukum, Volume 6, Nomor 2, Desember 2014), h. 138.

${ }^{3}$ Sami Zubaida, Law and Power in the Islamic World (London: LB. Tauris, 2012)

4 Athoillah Islamy, "Eksistensi Hukum Keluarga Islam di Indonesia dalam Kontestasi Politik Hukum dan Liberalisme Pemikiran Islam” (Al-Istinbath: Jurnal Hukum Islam, Volume 4, Nomor 2, November 2019), h. 162.

5 Tahir Mahmud, Family Law Reform In The Muslim World (Bombay: NM. Tripathi PVT LTD, 2010), h. 3-8. 
fikih klasik menuju hukum keluarga kontemporer hingga proses positifikasi hukum keluarga menjadi Undang-Undang. Hal itu diperuntukkan untuk mengetahui proses awal dan menentukan langkah selanjutnya jika ditemukan permasalahan-permasalahan baru yang tidak bisa dijawab oleh hukum keluarga saat ini dan diperlukan melakukan pembaharuan.

Signifikansi dari kajian ini adalah guna menentukan langkah dan model pembaharuan hukum keluarga Islam kontemporer. Hal ini sangat penting mengingatkan problematika hukum keluarga akan selalu muncul dalam ruang dan waktu yang berbeda. Sehingga diperlukan sebuah langkah pembaharuan hukum keluarga Islam yang lebih solutif dan bisa berdialog dengan sosio kultur masyarakat.

\section{HASIL DAN PEMBAHASAN}

\section{A. Melacak Sejarah dan Metode Pembaharuan Hukum Keluarga Islam}

Sebagai Negara yang pertama kali melakukan pembaharuan hukum keluarga, Turki melakukan langkah positifikasi hukum keluarga melalui Undang-Undang. Pandangan Sayyed Hossein Nasr, Turki merdeksi dari pendapat-pendapat dalam Madzab Hanafi. Pemikiran-pemikiran dalam Madzab Hanafi menjadi Madzab yang melatarbelakangi kehidupan keberagamaan secara formal. Pembaharuan hukum keluarga di Turki selanjutnya mengalami perkembangan yang cukup pesat dibandingkan dengan pemikiran-pemikiran fikih konvensional. ${ }^{6}$ Negara selanjutnya yang mengikuti jejak Truki adalah Negara Mesir, berbeda dengan Negara sebelumnya, Mesir mengadopsi hukum code civil switzerland. Negara Mesir melakukan pembaharuan hukum keluarga dengan melakukan langkah reformasi terhadap hukum-hukum fikih konvensional.

Pada tahun 1920 sebagai awal pembaharuan hukum keluarga di Mesir ditandai dengan positifikasi Undang-Undang tentang hukum keluarga. Sementara perubahan kedua dilakukan terhadap beberapa Pasal pada tahun 1929. Beberapa materi yang ada dalam hukum keluarga antara lain, ketentuan terkait waris, poligami, wasiat wajibah, dan pengasuhan anak. Kontribusi nyata yang dilakukan Turki serta Mesir dibuktikan dengan adanya pengaruh terhadap hukum keluarga dari kedua Negara tersebut. Sehingga Turki dan Mesir dijadikan Negara rujukan bagi terciptanya pembaharuan hukum keluarga Islam yang bisa merespon terhadap problematika dan perkembangan zaman. Sedangkan tujuan dari aktualisasi pembaharuan hukum keluarga ini bisa adaptif dan responsif terhadap problematika umat yang terus berkembang. ${ }^{7}$

Terkait dengan metode pembaharuan serta konsep hukum keluarga pada Negaranegara muslim, konsep dan metode pembeharuannya sebagai berikut: ${ }^{8}$

\section{Intra-doctrinal Reform}

Sebagaimana yang telah disabdakan oleh Nabi Muhammad tentang adanya persilangan pendapat di kalangan para mujtabid merupakan sebuah rahmat. Persilangan pendapat tersebut dibuktikan dengan perkembangan terhadap pengkajian dan penetapan hukum Islam yang elastis telah menimbulkan adanya suatu pendapat yang berbeda-beda di kalangan fuqaha' (ahli hukum Islam). Perbedaan pendapat dalam penetapan hukum Islam tersebut dibuktikan

\footnotetext{
${ }^{6}$ Lia Noviana, "Status Wanita di Negara Muslim Modern: Studi Terhadap Hukum Keluarga di Tunisia dan Indonesia" (Kodifikasia: Jurnal Penelitian Islam, Volume 13, Nomor 2, 2019), h. 199.

7 M. Nur Hasan Latief, "Pembaharuan Hukum Keluarga Serta Dampaknya Terhadap Pembatasan Usia Minimal Kawin dan Peningkatan Status Wanita” (NOVELTY: Jurnal Hukum, Volume 7, Nomor. 2, 2016), h. 197-198.

8 Tahir Mahmud, Family Law Reform In The Muslim World, h. 20-48.
} 
dengan adanya golongan madzhab dalam fikih, seperti madzhab Hanafi, Syafi'i, Maliki, dan Hambali.

Pembaharuan hukum keularga melalui metode intra-doctrinal merupaka sebuah meted pembaharuan yang dinisbatkan pada pendapat madzab tertentu yang diakui dan dianut oleh mayoritas masyarakat dalam sebuah Negara. Metode ini beberapa digunakan dalam Negara, seperti Mesir yang menganut madzab Syafi'i dan beralih pada madzab Hanafi dan Indonesia yang menganut madzab Syafi'i.

\section{Extra-doctrinal Reform}

Penggungaan metode extra-doctrinal reform dalam pembaharuan hukum keluarga merupakan sebuah metode pembaharuan yang keluar dari pendapat Imam Madzhab. Pendapat ini dilakukan dengan menggunakan pendekatan lain yang bisa beradaptasi bagi masyarakat. Beberapa hasil pembaharuan dengan menggunakan metode extra-doctrinal reform adalah wasiat wajibah, larangan poligami, dan lain sebagainya.

3. Regulatory Reform

Umat Islam selalu bersentuhan dengan tradisi-tradisi lain, termasuk bersentuhan dengan Negara barat. Persentuhan ini telah mempengaruhi hukum keluarga dalam beberapa hal, termasuk adanya berbagai prosedur administrasi. Seperti adanya ketentuan adminitrasi modern, dimana Negara yang menerapkan ketentuan ini telah menerapkan unsur administrasi dalam positifikasi hukum keluarga, seperti adanya pencatatan perkawinan. Beberapa Negara yang sudah menerapkan pembaharuan hukum keluarga dengan metode regulatory reform adalah Pakistan, Indonesia, Brunei Darussalam, Malaysia, dan Singapura.

\section{Codification}

Codification merupakan pembaharuan dengan menyatukan dan membukukan materi hukum dengan sistematis dan lengkap. Pembaharuan ini difahami sebagai pembaharuan yang diadopsi dari Negara Barat. Persentuhan anara umat Islam dan masyarakat barat pada masa kolonial menjadi awal mula pengadopsian metode ini. Akhirnya beberapa Negara muslim menciptakan sebuah kodifikasi dengan mengadopsi beberapa materi hukum Islam sebagai dasar pembaharuan. Di antara Negara-negara Islam yang sudah melaksanakan pembaharuan hukum keluarga dengan menggunakan metode codification adalah Lebanon, Syiria, Jordania, Maroko, Tunisia, dan Irak.

\section{B. Model Pembaharuan Hukum Keluarga Islam Pada Negara Muslim}

Menurut J.N.D Anderson Negara muslim memiliki tiga tipologi dalam melakukan pembaharuan hukum keluarga, di antaranya: 1) Negara yang masih menganggap syariah sebagai sebuah hukum dasar yang harus diterapkan; 2) Negara yang merevisi hukum syariah dan menggantinya dengan hukum barat yang sekuler; 3) Negara yang menggabungkan antara hukum syariah dan hukum sekuler. ${ }^{9}$

Sementara itu, Negara-Negara yang menerapkan hukum keluarga terbagi menjadi tiga kelompok Negara. Pertama, Negara yang menerapkan hukum keluarga berdasarkan dengan beberapa madzab secara asli yang diakui. Kedua, Negara yang melakukan peruubahan secara keseluruhan terhadap hukum keluarga dengan hukum yang lebih progresif dan modern. Ketiga, Negara yang menerapkan hukum keluarga melalui proses pembaharuan dan positifikasi melalui Undang-Undang.

${ }^{9}$ J.N.D Anderson, Hukum Islam di Dunia Modern (Islamic Law in The Modern World), terj. Machnun Husain (Yogyakarta: Tiara Wacana, 2009), h. 100-101. 
Dari penjelasan di atas, Negara yang merupakan bagian dari kelompok pertama yang menerapkan hukum konvensional dari pendapat madzab adalah Negara Saudi Arabia dan kedua adalah Yaman. Saudi menganut madzab Hambali dan Negara Yaman yang menganut madzab Zaidi, Syafi'i, dan Hanafi. Hukum keluarga pada kelompok pertama ini didasarkan pada Al-Qur'an, al-Hadis, dan syariat sahabat serta tidak dilakukan kodifikasi dan legislasi hukum.

Sementara Negara yang ada pada kelompok kedua ini adalah Negara yang sudah meninggalkan syariah dan menggunakan hukum modern dari Negara barat, yaitu Negara Turki dan Albania. Code Civil pada Negara Turki dimaksudkan untuk menggantikan hukum syariah yang diterapkan pada tahun 1926. Kelompok kedua ini juga diikuti oleh Negara-negara yang memiliki minoritas penduduk yang beragama Islam, seperti Zanzibar, Kenya, dan Tanzania yang menerapkan hukum keluarga berdasarkan hukum barat modern.

Sedangkan Negara yang masuk dalam kelompok ketiga yaitu Negara yang telah membaharui ketentuan hukum keluarganya berdasarkan proses legislasi dan positifkasi modern. Negara ini adalah Cyprus, dimana Negara ini menetapkan dan mengkodifikasikan hukum keluarganya pada tahun 1951. Sementara Negara dari Asia Tenggara diwakili oleh Indonesia, Malaysia, Singapura, dan Brunei Darussalam, serta Negara lain yang masuk dalam kelompok ketiga ini adalah Algeria, Iran, dan Lebanon. ${ }^{10}$

\section{Positifikasi Hukum Keluarga di Dunia Muslim Melalui Pembaharuan Hukum Keluarga}

Secara umum pembaharuan hukum keluarga pada Negara muslim yang kemudian menjadi hukum posiitif (hukum Negara) terkait dengan beberapa hal untuk kemajuan dan perbaikan. Di antara pembaharuan hukum keluarga yang merupakan sebagai langkah awal positifikasi mencakup beberapa bidang, yaitu:

1. Batas Usia Perkawinan

Dalam diskursus kajian fikih, usia perkawinan tidak ditentukan batasnya dengan menggunakan jumlah umur. Para ahli fikih menyebutkan aqil dan baligh, sedangkan aqil baligh ditandai dengan mimpi basah bagi pria dan haid bagi wanita. Namun demikian, dari beberapa Negara muslim sudah menerapkan batas usia minimal pernikahan bagi seorang pria dan wanita. Hal ini bertujuan guna mengurangi serta menghilangkan praktik perkawinan pada usia anak-anak. Pelaksanaan batas minimal umur perkawinan ini berimplikasi pada perkawinan seseorang yang belum memenuhi umur yang ditentukan, berarti perkawinannya tidak sah menurut hukum Negara, bahkan beberapa Negara juga memberikan sanksi berupa pidana bagi pelaku perkawinan anak di bawah umur.

Mengenai dengan batas usia perkawinan ini, beberapa Negara memiliki perbedaan masing-masing. Adapun beberapa ketentuan dari setiap Negara bisa di jelaskan dalam table sebagai berikut: ${ }^{11}$

10 Sri Wahyuni, "Pembaharuan Hukum Keluarga Islam di Negara-Negara Muslim” (al-ahwal: Jurnal Hukum Keluarga Islam, Volume 6, Nomor 2, 2013), h. 214-215.

11 M. Nur Hasan Latief, Pembaharuan Hukum Keluarga.., h. 206-207. 
Tabel 1. Batas Usia Pernikahan di berbagai negara

\begin{tabular}{|c|c|c|c|}
\hline No & Negara & Dasar Hukum & Ketentuan \\
\hline 1. & Aljazair & $\begin{array}{l}\text { "The Family Law Code } \\
1984 \text { Pasal 7" }\end{array}$ & $\begin{array}{l}\text { Ketentuan batas minimal usia } \\
\text { perkawinan dalah } 21 \text { tahun bagi } \\
\text { laki-laki dan } 18 \text { tahun bagi } \\
\text { perempuan. }\end{array}$ \\
\hline 2. & Yordania & $\begin{array}{l}\text { "The Code of Personal } \\
\text { Status } 1976 \text { pasal } 5 "\end{array}$ & $\begin{array}{l}\text { Ketentuan batas minimal usia } \\
\text { perkawinan di Yordania adalah } 16 \\
\text { tahun bagi laki-laki dan } 15 \text { tahun } \\
\text { bagi perempuan. }\end{array}$ \\
\hline 3. & Lebanon & $\begin{array}{l}\text { "The Law on Family Right } \\
\text { 1917-1962 pasal 4" }\end{array}$ & $\begin{array}{l}\text { Syarat utama diperbolehkan } \\
\text { melangsungkan perkawinan adalah } \\
\text { ketika laki-laki berusia } 18 \text { tahun dan } \\
\text { perempuan berumur } 17 \text { tahun. }\end{array}$ \\
\hline 4. & Tunisia & $\begin{array}{l}\text { "Pasal } 5 \text { ayat } 2 \text { Code of } \\
\text { Personal Status 1956-1981" }\end{array}$ & $\begin{array}{l}\text { Ketentuan batas minimal } \\
\text { perkawinan adalah usia } 20 \text { tahun } \\
\text { bagi laki-laki dan } 17 \text { tahun bagi } \\
\text { perempuan. }\end{array}$ \\
\hline 5. & Maroko & $\begin{array}{l}\text { "Mudawwanah al ahwal al } \\
\text { syakhsiyyah tahun 1957- } \\
\text { 1958, diatur pasal } 8 \text { dan } \\
\text { pasal 9" }\end{array}$ & $\begin{array}{l}\text { Usia perkawinan di Negara Maroko } \\
\text { adalah } 18 \text { tahun untuk laki-laki, } \\
\text { sedangkan untuk wanita } 15 \text { tahun. }{ }^{14}\end{array}$ \\
\hline 6. & Turki & "Code Civil 1926" & $\begin{array}{l}\text { Batas usia melakukan perkawinan } \\
\text { adalah saat laki-laki berusia } 18 \\
\text { tahun dan perempuan berusia } 17 \\
\text { tahun. }\end{array}$ \\
\hline 7. & Mesir & $\begin{array}{l}\text { "Ayat } 5 \text { pasal } 99 \text { Undang- } \\
\text { undang susunan pengadilan } \\
\text { agama tahun 1931" }\end{array}$ & $\begin{array}{l}\text { batas minimal melangsungkan } \\
\text { perkawinan adalah ketika laki-laki } \\
\text { berusia } 28 \text { tahun dan perempuan } \\
\text { berusia } 16 \text { tahun. }\end{array}$ \\
\hline
\end{tabular}

2. Pencatatan Perkawinan

Ajaran Islam (Al-Qur'an dan al-Hadis) tidak ditemukan sebuah penjelasan bahwa pencatatan perkawinan diwajibkan. Hal ini sangat berbeda dengan praktik mu'amalab (jual beli, sewa menyewa, dll.) yang diperintahkan untuk mencatatnya. Namun seiring dengan perkembangan dan tuntutan zaman serta mempertimbangkan mashlahah, dalam beberapa Negara Islam mengatur ketentuan pencatatan perkawinan guna kepentingan administrasi dan menjaga kepastian hukum. ${ }^{16}$

Penggalian hukum tentang pencatatan pernikahan ini di-qiyas-kan dengan Ayat AlQur'an Surat al-Baqarah Ayat 282 yang mengatur tentang pencatatan hutang piutang. Dalam ketentuan ayat ini beberapa ulama mewajibkan untuk mencatat hutang piutang serta mendatangkan saksi dihadapan pihak ketiga yang dipercaya. Hal ini menunjukkan

\footnotetext{
12 M. Atho' Mudzar dan Khairuddin Nasution, Hukum Keluarga di Dunia Islam Modern, (Jakarta Selatan: Ciputat Press, 2003), h. 125.

13 M. Atho' Mudzar dan Khairuddin Nasution, Hukum Keluarga di Dunia Islam, h. 87.

${ }^{14}$ M. Atho' Mudzar dan Khairuddin Nasution, Hukum Keluarga di Dunia Islam, h. 109.

15 M. Atho' Mudzar dan Khairuddin Nasution, Hukum Keluarga di Dunia Islam, h. 43.

16 Ahmad Rofiq, Hukum Perdata Islam di Indonesia (Jakarta: PT Raja Grafindo Persada, 2013), h. 91.
} 
bahwa ayat ini menekankan perlunya menuliskan ketentuan hutang walaupun hanya sedikit. Hal ini bertujuan untuk menghindarkan pada terjadinya sengketa di kemudian hari. ${ }^{17}$

Hampir semua Negara menerapkan kewajiban untuk rakyatnya mencatatakan akad pernikahannya pada instansi pemerintah yang ditunjuk. Meskipun dalam pelaksanannya di beberapa Negara ada perbedaan. Seperti di Negara Yordania yang memberikan denda lebih dari 100 Dinar ketika seeorang tidak mencatatkan perkawinannya pada Kantor atau Petugas yang berwenang. Ketentuan ini diatur dalam Pasal 17 Ayat 3 Law of Family Right. Selanjutnya jika pencatatan secara resmi tidak dilakukan oleh petugas yang berwenang, maka petugas akan menerima hukuman dan atau denda dan atau pemberhentian dari jabatannya, sebagaimana diatur dalam Undang-Undang Hukum Pidana Yordania Pasal 279.

Sementara di Negara Pakistan, akad perkawinan yang tidak dicatatkan pada lembaga yang berwenang, maka akan diancam hukuman penjara paling lama tiga bulan dan berupa denda sebanyak 1000 Rupees. Ketentuan ini diatur dalam Pasal 5 Muslim Family Law Ordinance Tahun 1961. Sedangkan Malaysia bagi penduduk yang melakukan akan perkawinan dan dalam waktu enam bulan tidak mencatatkan perkawinannya pada pejabat yang berwenang, maka akan diancam dengan hukuman denda sebesar 1000 Ringgit dan atau kurungan paling lama enam bulan. Ketentuan ini diatur dalam Undang-Undang Hukum Keluarga Tahun 1984 Pasal 33.

Negara terakhir adalah Brunei Darussalam, dimana Negara ini memberikan aturan bahwa setiap akad perkawinan hanya boleh dilaksanakan apabila dipimpin oleh orang yang diangkat oleh Sultan dan diberi kewenangan untuk memimpin pelaksanaan akad perkawinan. Beberapa Undang-undang hukum keluarga tahun 2000 Brunei Darussalam mengatur beberapa hal, diantaranya pasal 2 yang mengatur bahwa tidak boleh melangsungkan akad pekawinan sebelum mendapatkan izin dari pejabat pencatatan perkawinan. Pasal 3 mengatakan bahwa wali dapat menikahkan dan memimpin akad perkawinan hanya dihadapan petugas pencatat nikah (jurunikah) yang berwenang. Serta yang dikatakan dalam pasal 37 bahwa barangsiapa yang memimpin akad perkawinan tanpa mendapatkan izin dari sultan, maka akan diancam denda sebesar 2000 Ringgiit dan atau penjara paling lama enam bulan. ${ }^{18}$

3. Pengaturan Poligami

Poligami menjadi sebuah perbuatan yang dilegalkan oleh Islam dengan batasan empat orang istri. Namun kalangan para pemikir muslim kontemporer masih memperdebatkan permasalahan poligami. Terdapat ungkapan yang menyatakan bahwa poligami bukan merupakan sebuah ketetapan, tetapi sebagai bentuk pengecualian agar terhindar dari perbuatan yang keji. Maka dari itu, di Negara-negara Islam yang memiliki hukum keluarga sendiri cenderung mengontrol poligami.

Terkait dengan pengaturan poligami dalam hukum keluarga bisa diketahui dalam beberapa hal:

Pertama, menerapkan aturan yang ada dalam Al-Qur'an bahwa poligami diperbolehkan dengan syarat suami bisa berbuat adil. Sementara beberapa Negara Islam

${ }^{17}$ M. Quraish Shihab, Tafsir Al-Misbah (Jakarta: Lentera Hati, 2004), h. 602.

${ }^{18}$ Sejarah dan Reformasi Hukum Keluarga Islam di Dunia, https://www.radarhukum. com/sejarah-reformasihukum-keluarga-islam-di-dunia.html, Diakses pada tanggal 30 September 2019 pukul 11.45 WIB. 
yang memperbolehkan praktik poligami adalah Negara Lebanon, Maroko, Pakistan, dan India. Negara-negara diatas mengatur mengatur pembolehan poligami dengan syarat utama berupa adil. Kedua, pengaturan atas perjanjian tertulis pada saat akad perkawinan tentang tidak akan melakukan praktik poligami. Dimana seorang suami dan istri membuat kesepakan bahwa tidak akan pernah melakukan bagi laki-laki dan tidak pernah mengijinan bagi perempuan. Aturan seperti ini diterapkan di Negara Jordania dan Maroko.

Ketiga, ketentuan dan pengaturan bagi suami yang ingin melakukan poligami harus dapat ketetapan dan izin dari Pengadilan, ketetapan tersebut terkait dengan kondisi kesehatan dan finansialnya. Aturan ini diterapkan di Negara Iran, Irak, Syiria, Singapura, dan Malaysia. Keempat, pengaturan akan kontrol sosial, beberapa Negara seperti Indonesia dan Pakistan, menetapkan bahwa izin dari istri pertama di Pengadilan adalah syarat yang harus ditempuh oleh suami jika hendak melakukan poligami.

Kelima, pelarangan poligami, berbeda dengan Negara muslim lainnya, Turki dalam Code Civil tahun 1926 menyatakan secara tegas atas larangan perwaninan poligami. Akibatnya, jika seorang laki-laki yang telah memiliki istri yang sah namun tetap melakukan perkawinan, kedua perkawinan tersebut dianggap tidak sah menurut hukum. Keenam, pengaturan tentang pelarangan poligami, bahwa siapa yang melakukan poligami akan mendapatkan hukuman kurungan dan atau denda, seperti yang dilakukan oleh Negara Tunisia. ${ }^{19}$

4. Pembatasan Perceraian oleh Suami

Sebagai ikatan lahir batin dari seorang suami dan istri, selayaknya perkawinan diatur dalam peraturan Negara. Beberapa Negara Islam menerapkan hukum keluarga yang pada intinya membatasi adanya perceraian yang diajukan oleh suami. Meskipun secara fikih ketika seorang suami menjatuhkan talak, maka jatuhlah talak, namun ketentuan-ketentuan Negara sangat membatasi terjadinya perceraian. Penjelasan ini bisa diklasifikasikan sebagai berikut:

Pertama, adanya intervensi pengadilan, intervensi pengadilan dalam beberapa Negara Islam seperrti Iran, Irak, Aljazair, Turki, dan Tunisia, serta Negara Asia yaitu Malaysia, Indonesia, dan Singapuramemberlakukan perceraian oleh suami harus melalui pengadilan. Peraturan dalam Negara diatas dianggap sah sebuah perceraian jika sudah terdapat putusan pengadilan. Namun sebelum jatuhnya putusan pengadilan, ketentuannya adalah adanya mediasi (perdamaian) antara kedua belah pihak, jika memang sudah tidak bisa di damaikan, maka putusan perceraian ditetapkan. Penjelasan ini tentu bisa disimpulkan bahwa perceraian sedikit di minimalisir.

Kedua, intervensi administrasi, intervensi administrasi ini salah satunya diatur dalam Undang-undang hukum keluarga tahun 1961 Pakistan Seorang suami yang telah menjatuhkan talak kepada isterinya akan mendapatkan fasilitas dari lembaga arbitrase yang ditunjuk oleh kantor catatan sipil. Lembaga arbitrase ini memiliki peran untuk mengupayakan perdamaian dan rujuk pasangan suami isteri tersebut. Perceraian dapat dilangsungkan setelah berakhir waktu sembilan puluh hari dihitung sejak tanggal ditetapkannya catatan yang dikeluarkan oleh catatan sipil.

Ketiga, pembatasan secara tidak langsung. Intervensi administrasi dan pengadilan tidak berlaku di beberapa Negara Muslim. Beberapa Negara tersebut masih memegang teguh terhadap fiqih konvensional. Beberapa Negara-negara Islam mengakui bahwa hak

${ }^{19}$ Sri Wahyunu, Pembaharuan Hukum Keluarga Islam..., h. 215-216. 
suami untuk menjatuhkan talak kepada istri. Faham ini diikuti oleh Negara Sudan, Mesir, Lebanon, Syiria, Jordania, Maroko, serta Iran menerapkan bahwa ucapan talak suami harus benar-benar bermaksud untuk mengungkapkan kehendak suami dan tidak ada unsur paksaan untuk menjatuhkan talak kepada suami.

Keempat, pembatalan talak tiga sebagai wujud ucapan talak. Meskipun dalam kajiankajian fiqih konvensional talak yang dianggap sebagai jatuhnya talak adalah talak tiga, namun pembaharuan hukum keluarga menganggap bahwa yang bisa menjatuhkan talak adalah putusan pengadilan. Ketentuan ini bisa ditemukan di Indonesia yang menganggap bahwa talak yang sah adalah ketika sudah ada putusan dari pengadilan. ${ }^{20}$

5. Perceraian yang Diajukan Istri

Fiqih menegaskan bahwa hak talak ada pada suami, namun tidak menutup kemungkinan bagi seorang istri dapat meminta cerai dari suami. Hak seorang istri untuk meminta cerai kepada suaminya biasa disebut dengan fasakh. Tidak heran jika di ketentuan di Negaranegara Islam tentang perceraian yang diajukan oleh isteri terdapat dalam hukum keluarganya. Alasan yang dibenarkan oleh pengadilan bagi seorang istri yang meminta cerai dari suaminya di antaranya adalah suami gagal dalam memenuhi kewajibannya untuk memberikan nafkah. suami mempunyai cacat atau keterbatasan fisik serta gangguan mental serta penyakit yang sulit disembuhkan, pergi dari rumah dan tidak kembali, menyakiti dan melakukan kekerasan terhadap istri, serta melakukan kejahatan dan di hukum. Ketentuan lain bisa dilihat di Iran, apabila seorang suami melakukan poligami sedangkan istrinya tidak mengizinkannya, seorang istri dapat mengajukan perceraian ke muka pengadilan, ketentuan ini juga berlaku di Negara Pakistan dan India.

6. Status Hukum Anak

Anak yang lahir dalam perkawinan yang sah disebut dengan anak yang sah. Salah satu bukti bahwa hukum keluarga Islam memperhatikan status hukum anak adalah adanya ketentuan mengenai masa 'iddah yang memiliki tujuan utama untuk mengetahui status hukum anak. Hukum keluarga di beberapa Negara Muslim masa ini mengatur ketentuan terkait masa 'iddah, hak nafkah, hak waris bagi istri serta status anak. Masa 'iddah di Negara Mesir dan Sudan ialah tidak melebihi satu tahun. Di India dan Pakistan ketentuan terkait status anak yang lahir dalam masa 'iddah sedang ibunya belum menikah dengan orang lain, anak tersebut berstatus sebagai anak sah dari perkawinan sebelumnya.

Sementara itu, mengenai hukum kewarisan, dikenal adanya pewarisan secara intestate dan pewarisan secara testament. Pewarisan secara intestate dapat terjadi karena adanya kekerabatann, golongan darah, dan hubungan perkawinan. Sedangkan pewarisan testament merupakan pembagian harta waris karena adanya sebuah wasiat. Negara mesir, Syiria, Tunisia, dan Maroko adalah beberapa Negara Muslim yang berhasil membuat Undangundang tentang hukum kewarisan secara komprehensif. Sementara Negara Sudan, Irak dan Pakistan tetap berpegang pada konsep hukum kewarisan Islam klasik dengan sedikit melakukan beberapa pembaharuan.

Pembaharuan yang dilakukan dalam ranah hukum kewarisan diantaranya adalah: pertama, cucu mendapatkan hak waris melaui wasiat wajibah. Cucu mendapatkan hak warisnya apabila orang tuanya telah meninggal dunia. Seperti yang kita ketahui dalam konsep hukum Islam klasik cucu sama sekali tidak berhak atas harta waris karena memiliki

${ }^{20}$ Sri Wahyunu, Pembaharuan Hukum Keluarga Islam.., h. 216-217. 
kedudukan yang jauh. Berbeda dengan kondisi saat ini dimana beberapa Negara Muslim telah memberikan hak waris kepada cucu jika orangtuanya selaku ahli waris telah meninggal dunia. Konsep inilah yang disebut dengan konsep wasiat wajibah. Diantara Negara muslim yang mengatur ketentuan wasiat wajibah diantaranya adalah Mesir, Maroko, Pakistan, Tunisia, dan Syiria.

Kedua, pasangan yang masih hidup. Pasangan yang masih hidup dalam hukum kewarisan Islam tradisional mendapatkan bagian sesuai yang termaktub dalam al-Qur'an furuddul muqaddarah. Apabila terdapat kasus hanya ada pasangan yang masih hidup, sisa harta warisan dapat diberikan ke baitul mal atau Negara. Mengenai pasangan, sesuai ketentuan furuddul muqaddarah bagian untuk suami adalah setengah dan isteri mendapatkan bagian seperempat dari harta warisan.

Hukum kewarisan Islam di Negara muslim seperti Mesir, Sudan, Syiria, Tunisia, India dan Pakistan memberlakukan hukum waris bagi pasangan yang masih hidup untuk mendapatkan seluruh harta warisan jika dia satu-satunya ahli waris yang tersisa. Ketiga, wasiat bagi ahli waris. Menurut hukum kewarisan Islam klasik, ahli waris tidak boleh menerima wasiat. Namun di Negara Mesir, Sudan dan Irak wasiat boleh diberikan kepada ahli waris. ${ }^{21}$

\section{Model Baru Pembaharuan Hukum Keluarga Islam}

Model pembaharuan dan langkah positifikasi hukum keluarga Islam di Negara-negara muslim. Untuk menemukan sebuah langkah pembaharuan (dalam hukum Islam disebut dengan ijtihad) yang progresif. Namun demikian, problematika hukum keluarga selalu bermunculan dalam setiap ruang dan waktu. ${ }^{22}$ Model pembaharuan baru berupa pendekatan mashlahah dalam menyelesaikan semua problematika hukum keluarga. Pendekatan ini diperuntukkan guna memberikan perlindungan bagi semua pihak. Sementara pendekatan ini memiliki berbagai sudut pandang dalam menentukan hukum (mashlahab). Seperti ditinjau dalam konteks kesehatan, psikologi, sosial, dan hukum Islam.

Guna merealisasikan pendekatan ini, perlu kiranya meninjau semua problematika hukum keluarga dengan berbagai sudut pandang. Sehingga akan menghasilkan produk hukum yang lebih progresif, dinamis, dan bisa merespon berubahnya tempat dan berkembangnya waktu. Wal hasil, hukum keluarga Islam akan mampu mewujudkan cita-cita hukum Islam berupa "shalib fi kully zaman wa al-makan".

\section{KESIMPULAN}

Positifikasi hukum keluarga melalui pembaharuan hukum keluarga Islam di Negara-Negara Muslim yang diawali oleh Negara Turki dan dilanjutkan oleh Mesir. Tujuan pembaharuan ini berkaitan dengan perbaikan dan kemajuannya, diantara pembaharuan tersebut adalah dalam bidang usia perkawinan dan perwalian, pencatatan perkawinan, kontrol terhadap poligami, perceraian dari suami, perceraian yang diajukan oleh istri dan status hukum anak. Hal itu tentu

${ }^{21}$ Sri Wahyunu, Pembaharuan Hukum Keluarga Islam..., h. 217-218.

${ }^{22}$ Lebih lanjut mengenai formulasi konsep mashlahah, lihat dalam, Iffatin Nur dan Muhammad Ngizzul Muttaqin, "Reformulating The Concept of Mahlahah: From A Textual Confinement Towards A Logic Determination" (Justicia Islamica: Jurnal Kajian Hukum dan Sosial, Volume 17, Nomor 1, 2020). 
bertujuan untuk merspon problematika hukum keluarga kontemporer yang tidak lagi bisa direspon oleh fikih klasik.

Merespon akan kemunculan problematika hukum Islam kontemporer, pembaharuan hukum keluarga menggunakan pendekatan mashlahah. Hal itu menjadi solusi penting dalam menentukan arah positifikasi hukum keluarga Islam. Pembaharuan melalui pendekatan mashlahah akan lebih bisa diterima oleh ruang tempat dan waktu yang berbeda. Selain itu, pembaharuan melalui pendekatan mashlahah lebih bisa merespon berkembangan ilmu pengetahuan, seperti kesehatan, sosial, psikologi, dan hukum Islam kontemporer.

\section{REFERENSI}

Anderson, J.N.D. Hukum Islam di Dunia Modern (Islamic Law in The Modern World), terj. Machnun Husain, Yogyakarta: Tiara Wacana, 2009.

Ghofur, Abdul, dan Sulistiyono. "Eklektisisme Dalam Taqnin Hukum Keluarga Di Dunia Islam”. ISLAMICA: Jurnal Studi Keislaman, Volume 8, Nomor 2, Maret 2014.

Islamy, Athoillah. "Eksistensi Hukum Keluarga Islam Di Indonesia Dalam Kontestasi Politik Hukum dan Liberalisme Pemikiran Islam". Al-Istinbath: Jurnal Hukum Islam, Volume 4, Nomor 2, November 2019.

Latief, M. Nur Hasan. "Pembaharuan Hukum Keluarga Serta Dampaknya Terhadap Pembatasan Minimal Kawin dan Peningkatan Status Wanita". NOVELTY: Jurnal Hukum, Volume 7, Nomor 2, 2016.

Mudzar, M. Atho' dan Khairudin Nasution. Hukum Keluarga di Dunia Islam Modern. Jakarta: Ciputat Press, 2003.

Noviana, Lia. "Status Wanita di Negara Muslim Modern: Studi Terhadap Hukum Keluarga di Tunisia dan Indonesia". Kodifikasia: Jurnal Penelitian Islam, Volume 13, Nomor 2, 2019.

Nur, Iffatin dan Muhammad Ngizzul Muttaqin. "Reformulating The Concept of Mashlahah: From A Textual Confinement Towards A Logic Determination". Justicia Islamica: Jurnal Kajian Hukum dan Sosial, Volume 17, Nomor 1, 2020.

Rofiq, Ahmad. Hukum Perdata Islam di Indonesia. Jakarta: PT Raja Grafindo, 2013.

Sejarah dan Reformasi Hukum Keluarga Islam di Dunia, dalam, https://www.radarhukum.com/sejarah-reformasi-hukum-keluarga-islam-di-dunia.html

Shihab, M. Quraish. Tafsir Al-Misbah. Jakarta: Lentera Hati, 2004.

Tahir, Mahmud. Family Law Reform In The Muslim World. Bombay: NM. Tripathi PVT LTD, 2010.

Wahyuni, Sri. "Pembaharuan Hukum Keluarga Islam di Negara-Negara Muslim”. al-Ahwal: Jurnal Hukum Islam, Volume 6, Nomor 2, 2013.

Zubaida, Sami. Law and Power in the Islamic World. London: LB. Tauris, 2012. 